\title{
ISMAIL TAŞ
}

(Konya, Turcja)

\section{A TRANSFORMATION IN ISLAMIC THOUGHT: THE HOUSE OF WISDOM (BAYT AL-HIKMAH) IN THE CONTEXT OF OCCIDENTALISM VERSUS ORIENTALISM}

One may speak of different factors and sources that might have played some role in the formation of a thought, a philosophy, a culture, and a civilization. The richness and vividness of all these human products is also assessed according to the diversity of the sources from which they are nurtured. In this context, one may talk of an ancient Egyptian, an ancient Greek and a Roman thought and civilization as well as of a variety of intellectual, cultural and civilizational components and propensities that might have impacted them. While some of these influences took place through the centuries-long interactions between different peoples, the others occurred as a result of the interplays between the conquering and the conquered nations and civilizations. In this sense, we find that the ancient Egyptian civilization merged into the Greek civilization which in turn coalesced into the Latin and Islamic civilizations, all of them flowing into the European civilization as consequence of the process inaugurated by the Renaissance. But one should note that these successive incorporations are more a reincarnation of the earlier civilization in the later than the annihilation of the former in the latter. Therefore, it is indispensible for the survival of any civilization to find the channels of self-enrichment. As one of such channels is the voluntary interaction with the neighbors, the other is the material and spiritual shocks a civilization undergoes in the course of time. ${ }^{1}$

\footnotetext{
1 Consult Fernand Braudel, Uygarlıkların Grameri (Grammar of Civilizations), Turkish translation by M. Ali Kılıçbay, Istanbul: İmge Publishing, 2001, pp. 40-67.
} 
However, there is another way that played a decisive role in the formation of Islamic thought and civilization: the conscious endeavors to have access to the intellectual and scientific achievements of another civilization through translations. As pointed out by the late Turkish historian of thought, Hilmi Ziya Ülken (1901-74), any substantial intellectual awakening in the history of mankind has always been preceded by a great translation activity. For instance, the ancient Greek renaissance followed the Anatolian, Phoenician and Egyptian translations, the Islamic renaissance arose in the wake of the Greek and Indian translations, and the Western renaissance came about through the Islamic (Arabic, Turkish, and Persian), Greek and Hebrew translations. The German renaissance that began in the eighteenth century added new products of the Latin and Anglo-Saxon world to the old heritage. So this vigorous German translation activity, prepared by the Enlightenment, gave birth to the creative German thought. If the ancient Greeks, the Muslim nations, the Renaissance nations, the German romanticism created anything new and partook of the constant civilizational expansion, this took place primarily as a result of the very rich preparatory translations and then of the profound and intrinsic reactions to this cultural and intellectual grafting. ${ }^{2}$ This process is well exemplified by the Muslim endeavors to comprehend the philosophical thought produced mainly if not solely by the ancient Greeks, and by the impact this thought had on the Islamic culture in both material and spiritual realms.

As we will discuss soon, philosophy in its strict technical sense seems to be an alien element introduced into the body of Islamic thought by the external efforts and motives. But this does not mean that no Islamic thought had existed prior to the Muslim encounter with the ancient Greek philosophy. From this point of view, one should well consider the rise and development of Islamic thought.

Though it stemmed primarily from the Qur'ān, the revealed book of Islam, and the hadith, known as the sayings of the Prophet Muhammad, Islamic thought assumed a systematic form as a result of the creative amalgamation of the genuinely Muslim achievements and foreign elements. Some Orientalists claim that even the methodology of jurisprudence (usūl al-fiqh) and syllogistic reasoning ( qiy $\bar{a} s$ ) are the results of the Jewish and Christian influence even before the Muslim encounter with the Greek philosophy. ${ }^{3}$

However, most of the modern researchers of the Islamic thought hold that the Muslims from the very beginning of their civilization have progressed step

\footnotetext{
2 See H. Z. Ülken, Uyanış Devirlerinde Tercümenin Rolü, Istanbul: Ülken Publishing, 1997, pp. $15-16$.

3 See Muhammad 'Alī Abū Rayyān, Ta'rīkh al-Fikr al-Falsafĩ fì al-Islām, Beirut: Dār al-Nahdah al-'Arabiyya, 1976, pp. 19-20.
} 
by step in search of knowledge. In the early years of Islam, they were engrossed in the sciences of the Qur'ān and sunna, namely, the practice of the Prophet, reaching legal rulings by deepening in these sciences and setting forth religious postulates to defend and justify their positions against their religious and sectarian adversaries. ${ }^{4}$ This process gave rise to the science of dialectical theology and jurisprudence. As a result of their focusing on the creedal and legal issues, the methodology of jurisprudence developed. Therefore, one can hardly describe this intellectual progress as an exclusive result of the alien influences.

Some of the Muslims in this stage of history searched Greek philosophy by translating the Greek philosophical lore into Arabic and by studying its problematics and achievements. In the next stage, they tried to harmonize the tradition of Greek philosophy with the teachings of Islam. ${ }^{5}$ Thus, although Islamic philosophy and the philosophers exercised a deep impact on most of the Islamic disciplines, one cannot reduce the Islamic thought to Islamic Philosophy in the strict sense of the term. It would therefore be more in harmony with the historical facts to regard Islamic Philosophy as one of the major components of Islamic thought, and not as the whole of it.

Besides the linguistic and religious disciplines, medical science was the only science to receive a due attention from the Muslims in the early years of Islam. Since all the people needed a medical treatment and care, this non-religious science suffered no popular antipathy. Though one may consider this attitude to be simply a result of natural need and necessity, we however want to call attention to the recommendation related as the saying of the Prophet Muhammad: "O servants of God, try to heal yourselves because God created no disease but that he also created its cure, except for senility." ${ }^{6}$ In the course of time, the Muslims however did not shy away from borrowing the intellectual, institutional as well as administrative instruments necessary to their social, political, and economic life. One such institute was the House of Wisdom (Bayt al-Hikmah) that paved the way for systematic thought in the Muslim lands.

That the sources of reference other than the Qur'ān and the sunna came into play in company with the mental transformation boosted by the House of Wisdom should be taken as a consequence of the process that had been at work from the very outset. Therefore, one needs to pay a due attention to the intellectual

\footnotetext{
4 For such a theological-philosophical debate, see Tahir Uluç and Kemal Argon, "Reflections on the Unity/Trinity Polemics in Islamic Philosophy: Yahyā bin 'Ad̄̄ and His Maqālah fī al-Tawhīd (Treatise on Unity)", Journal of Middle Eastern and North African Intellectual and Cultural Studies, vol. 4, issue 2, Fall 2006, p. 133 and on.

5 Abū Rayyān, Ta'rīkh al-Fikr, p. 21.

6 See Abū Qāsim ibn Sa‘id al-Andalus̄ì, Tabaqāt al-Umam, Beirut: Imprimerie Catholique, 1912 , p. 47.
} 
atmosphere in the Umayyad rule preceding the 'Abbasid reign. Without going into much detail, we can make the following remarks on the issue: The Umayyad period may be viewed from an intellectual and ideological perspective as a period of gestation in which the Muslim community began to discuss its internal problems aloud - a process that would result in the rise of various Islamic schools of thoughts. In other words, rudiments of the intellectual currents that would become full-fletched schools in the subsequent years appeared in the Umayyad period. This is why all of the classic and modern currents, creedal, legal, or political, have always tended to establish their legitimacy with an unfaltering reference to this formative phase of Islam. But one should note that the philosophical foundations upon which the dialectical theology as wielded by different schools as means of defending and expressing their respective doctrines and ideologies relied were laid as early as the late years of the first century of Islam. ${ }^{7}$

We also observe that the first steps of science were also taken in the Umayyad period, in which the Muslims showed a particular interest in medical sciences. The biographers and historians of Islamic science draw a special attention to the studies and activities of Khālid bin Yazīd (d. 704) in the field of chemistry. ${ }^{8}$ The Muslim community however experienced its fundamental transformation under the 'Abbasid rule for the scope of change in this period transcended the political and territorial expansion of the Empire, characterized by a huge diversity in the social, religious, and intellectual sources of reference in parallel to the variegation of ethnic and religious components of the Empire.

This transformation goes as far back as to the early years of the 'Abbasid rule. We know that the second 'Abbasid caliph al-Mansūr (reigned 754-775) adopted the Sasanid political doctrine, selecting his top functionaries from the former Sasanid bureaucrats due to the fact that the Persians reached their apogee in political culture and administrative skills long ago. Since the Persians embraced and surrendered to Islam, they would serve al-Mansūr and the 'Abbasid dynasty faithfully. It seems that al-Mansūr's successors followed in his footsteps for we observe a deep and continuing Persian influence over the 'Abbasid rule and court life. For example, we can mention the Barmakī and Nawbakht families that had a considerable political and intellectual power in the Empire. This strong Persian influence persisted until the year 818 when al-Fadl ibn Sahl, the vizier and close friend of al-Ma'mūn, was assassinated. ${ }^{9}$

\footnotetext{
7 See Khalīl Dāwūd Zarou, al-Hayāt al-'Ilmiyya fĩ al-Shām, Beirut: Dār al-Āfāq al-Jadīdah, 1971, pp. 209-210.

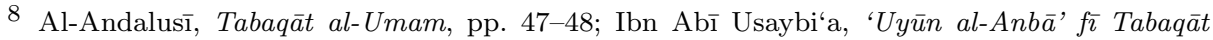
al-Atibbā', Beirut: Dār Maktabat al-Hayāh, 1965, p. 161, 171, 175, 176, 177, 179.

9 Dimitri Gutas, "al-Fikr al-Yūnān̄̄ wa al-Thaqāfah al-"Arabiyyah", Arabic translation by Nicola Ziyādah, Beirut, 1998, Ircica 44175.
} 
The fact that the 'Abbasid family came to power with the Persian support earned the Persian subjects a privileged position in the nascent Empire. This collaboration brought them close to the caliphs and earned their favor. In fact, this should be taken as something new that would lead to the formation of Islamdom in the fullest sense of the term. Differently from the Umayyad period, the Arabs thus came into contact with the non-Arabs and came under their influence. This paved the way for the influx of foreign cultural and intellectual elements into the Arabic language, leading to the rise of free intellectual movements under the rules of Hārūn al-Rashīd (reigned 752-774) and al-Ma'mūn (reigned 786-808), a period to be viewed as the Golden Age of Islam or the Islamic Enlightenment. ${ }^{10}$

Given the fact that many scientists and scholars of different ethnicities and faiths offered valuable services in particular to the 'Abbasid rulers, one can assert that the 'Abbasids opened their doors not only to the people of Persian offspring but also to other ethnic as well as religious groups. This is well documented by the following statement in Tabaqāt al-Umam: "There was a group of Christian and Sabean scholars who were not known whether Greek or Roman or from other neighboring peoples." 11 These people not only offered a practical use in medicine, but also acted as the messengers and conveyors of their native cultural and intellectual heritage into the growing Islamic civilization. In this context, we can say that this ethnically and culturally cosmopolitan settings united the Eastern and Western culture. ${ }^{12}$ I want to mention some of the scholars and scientists who lived in the early years of the 'Abbasid rule.

Buhtishu': Being an Assyrian name, it means literally the "servant of Messiah." It is a generic title that was given to many a scholar in this period. Therefore it seems impossible to identify the real names of the scholars who were invested with this title. However, what is of interest to us here is that the holders of this title came from a foreign religious and cultural background. ${ }^{13}$

Yuhanna bin Masawayh: He was born in Jundishapur in the year 777 and grew up in Baghdad. Such biographers as Ibn Nadīm, Qiftī, Ibn Ab̄̄ Usaybi‘a, and Ibn Juljul enumerate his many books. ${ }^{14} \mathrm{He}$ is said to be one of the early translators

10 See Abū Rayyān, Ta'rīkh al-Fikr, p. 61; Şahin Filiz and Tahir Uluç, "Mawlānā Jalāl al-Dīn Rūmī: A Sufi Representative of Turkish Urban Religiosity (A Philosophical and Sociological Inquiry)", The Islamic Quarterly, vol. 48, Issue 4, Fourth Quarter 2004, p. 68.

11 Al-Andalus̄i, Tabaqāt al-Umam, p. 36.

12 See Ramziya Muhammad al-Atrāqch̄̄, "Bayt al-Hikmah al-Baghdādī wa Atharuhū fì al-Harakah al-'Ilmiyyah", al-Muarrikh al-'Arabi, Baghdad, vol. 14 (1980), p. 333.

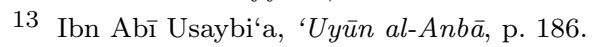

14 See Bahjat Kāmil 'Abdullatīf, "Yuhanna bin Masawayh: Awwalu Raīs li-Bayt al-Hikma al-Baghdādī wa Rāid min Ruwwādi 'Ilm al-Tashrīh wa al-Tibb fī al-Khilāfah al-'Abbāsiyyah" (in Bayt al-Hikma al-'Abbāsiyyah 'Araqat al-Mād̄̄ wa Ru'yat al-Hādir, 2001) vol. II, pp. 7-35. 
in the Islamic period. He served as a royal physician to the 'Abbasid rulers like Hārūn al-Rashīd, al-Ma'mūn and kept this office until the reign of al-Mutawakkil. Hārūn al-Rashīd put him in charge of the translation of the ancient works. From the books attributed to him, he seems to have specialized in medical sciences. ${ }^{15}$

Hunayn bin Ishāq: Being a pupil of Yuhanna bin Masawayh, he mastered the Greek and Arabic languages. He edited and clarified the previously translated books in medical sciences. Having two sons, Ishāq and Dāwūd, he wrote books in logics and medical sciences. While Ishāq specialized in translation and mathematical sciences, Dāwūd studied medical sciences. ${ }^{16}$

Abū al-Hassan Thābit bin al-Qurrā: Of Sabean origin, Abū al-Hassan is a polymath scholar and an expert in philosophy. He wrote books on logics, mathematics, geometry, and astronomy. He is a contemporary of al-Kindī and Qusta bin Luka. These three are famous in science and philosophy in their age in the Muslim world.

During the reign of al-Ma'mūn, Thābit bin al-Qurrā carried out solar observations in Baghdad, which he wrote down in a book explaining his views on the solar year. His son Sinān bin Thābit (d. 942) was also an expert in mathematics, geometry, and medical sciences. Sinān had a son who was well-versed in medical sciences. ${ }^{17}$ Kātib Chalabī (d. 1656) in his Kashf al-Zunūn underlines the role Thābit played in the translation activities with some exaggeration as the following: "Were not for the translations of Thābit bin al-Qurrā, no one could have made use of the books on wisdom because no one knew Greek. As a matter fact, all the books that he had not translated remained as such and none could benefit from them." 18

At the time when the "Abbasids came to power, there had been a strong tendency to revive the literary and human sciences. The second 'Abbasid caliph al-Mansūr took the lead in this revival. He founded new institutes in the new capital city of Baghdad and acquired many books on mathematics and astronomy from India. ${ }^{19}$

Al-Ma'mūn, who succeeded Hārūn al-Rashīd in the year 813, was an intelligent and ambitious caliph. He adopted and backed up the Mutazilite doctrine that advocated the interpretation and defense of the Islamic principles on ra-

\footnotetext{
15 Al-Andalusī, Tabaqāt al-Umam, p. 36.

16 Al-Andalusī, ibid, p. 37.

17 Al-Andalusī, ibid, p. 37.

18 Kātib Chalab̄̄, Kashf al-Zunūn 'an Asāmī al-Kutub wa al-Funūn, Istanbul: 1941, vol. II, p. 1594 .

19 Colin A. Ronan, "The Earliest Science in Arabia", The Cambridge Illustrated History of the World's Science, Cambridge: Cambridge University Press, 1983, pp. 204-205.
} 
tional grounds, just as done by the Greek and Alexandrian philosophers earlier. Then the Mutazilite discourse elicited a need to translate more Alexandrian and Greek literature on philosophy. Thus, al-Ma'mūn set up in Baghdad the House of Wisdom (Bayt al-Hikmah) that functioned mainly as a translation office, most of whose staff were Christians. Hārūn acquired most of the manuscripts from the Byzantine. ${ }^{20}$

In fact, the acquisition of books from abroad was a well-established custom prior to al-Ma'mūn and he thus just continued this custom because we know that al-Mansūr and Hārūn al-Rashīd also had acquired books from abroad and Hārūn accepted books for tax. ${ }^{21}$ Though one may view Hārūn's interest in the ancient books as a personal passion, it is however more probable that this is a reflection of the growing Muslim interest in foreign intellectual and cultural products.

Developed as an important cultural and scientific center after the 'Abbasids coming to power, Baghdad and the House of Wisdom with its staff and products reflected the ethnic, religious and cultural diversity of the 'Abbasid aristocracy and politics. Baghdad then exhibited a quite cosmopolitan picture, hosting scholars and medical scientists of all religions and ethnicities. ${ }^{22}$

The historical sources that address the rise of science and philosophy in the Islamic world agreed that rational and positive sciences entered into the Islamic world through the translations from the Greek, Assyrian, Indian and Pahlawi sources. Furthermore, the same sources, ranging from al-Fihrist by Ibn al-Nadīm (d. 385/995) to al-Muqad-dima by Ibn Khaldūn (d. 808/1406) acknowledge that these translations were accomplished mostly by the non-Arab and non-Muslim scholars. ${ }^{23}$ Therefore, the fact that a variety of languages came into play in the transmission of the Greek philosophy into Arabic seems to be quite normal. Of the languages that served as a bridge between the Greek and Islamic philosophy, Assyrian is undoubtedly the most important one for it was the medium of the Greek philosophy prior to Arabic. Nevertheless, it seems difficult to make an accurate assessment of the precise role the Assyrian language played in the process of the transmission because most of the Assyrian philosophical literature got lost. The surviving Assyrian manuscripts are limited to a few treatises on the Aristotelian logics and almost nothing has come down to us of the Galenic and

\footnotetext{
20 See Ronan, ibid., p. 204-205.

21 See Hadar Ahmad 'Atāullāh, Bayt al-Hikmah fī 'Asr al-'Abbās̄̄yȳ̄n, Cairo: Dār al-Fikr al-'Arabī, no date, p. 30.

22 See al-Atrāqch̄̄, "Bayt al-Hikmah", p. 317.

23 See George Saliba, "Translation and Translators, Islamic", Dictionary of the Middle Ages ed. by Joseph R. Strayer, New York: American Council of Learned Societies, 1989, vol. XII, pp. 127-133.
} 
Hippocratic medical literature. Therefore, it is difficult to establish Assyrian's role of intermediacy except for few anecdotes. ${ }^{24}$

However, the sources of history inform of the existence of a center in the 'Abbasid period where the ancient works were translated and studied. This center, which can be well regarded as an official and institutional expression of the mental transformation taking place in the Islamic world, is usually referred to as Bayt al-Hikmah, i.e., the House of Wisdom. The House of Wisdom therefore begs for an in-depth survey in connection with the formation of the classic Islamic thought. For though the early translations focused on the medical works and seemed to have been largely motivated by practical needs, they however in the subsequent stages came to introduce their native immaterial culture, namely, philosophy into the Islamic world. Posterior to these translations, the Muslims began to make references to different sources. The majority began to hold the notion that if one is sick, he should seek the remedy from the medical sciences, and if one seeks the sound thinking, he should take recourse to logics. In short, the people came to realize that religion and religious thought is not the right place to seek the solution of all sorts of worldly problems. Moreover, the Muslims came into acquaintance with philosophy whose origin is largely human reason. In doing so, they added to the body of Islamic thought an important dialectical element versus the pure religious thought.

The 'Abbasids set up the House of Wisdom to facilitate the translation and study of ancient sciences. We have already pointed out that the then Baghdad had a very cosmopolitan character and was one of the most important cultural and scientific centers to which the scholars and physicians of different religions and ethnicities made their way. ${ }^{25}$ Some researchers describe the House of Wisdom in similar terms.

The House of Wisdom was the first center of higher education founded in Baghdad. Next to this school, there was a translation office and an observatory, three of them forming the complex of the House of Wisdom. Departing from the various functions of the House of Wisdom, some sources make exaggerated remarks, describing the House of Wisdom as one of the oldest universities in the world. ${ }^{26}$

Some sources credit the honor of establishing the House of Wisdom to Hārūn al-Rashīd. However, it seems impossible to ascertain when and where of Baghdad the House of Wisdom was founded. As it might be inside the haram of the court, it might be built outside the court to facilitate the public access, too. The sources

\footnotetext{
24 Saliba, ibid., p. 129.

25 See al-Atrāqch̄̄, "Bayt al-Hikmah", p. 317.

26 See al-Atrāqch̄̄, "Bayt al-Hikmah", p. 318.
} 
provide no detailed information on the vicinity of the House of Wisdom. But one can estimate that the House must have had saloons for scholarly sessions, offices for the translators and for the other staff. Given the fact that Hunayn bin Ishāq worked on translation and on the related jobs together with his assistants in the House, one may assume that there was a school or a similar institute where the skill of translation was taught. For Ibn Ab̄̄ Usaybi'a (d. 668/1270) and some other historians inform that a number of translators worked in the House, most of them being Persian. ${ }^{27}$

The House of Wisdom reached its peak of development during the reign of al-Ma'mūn for the movement of translating the scientific works from different languages into Arabic began to bear fruit. Ibn Abī Usaybi'a relates that after the Muslim expansion into the Byzantine lands like Ankara and Amuriya, Hārūn al-Rashīd put Yuhanna bin Miskawayh in charge of Khizānah al-Hikmah, i.e. the Library of Philosophy. ${ }^{28}$ In fact, Bayt al-Hikmah and Khizānah al-Hikmah were used interchangeably, a fact showing that Bayt al-Hikmah was initially a library. ${ }^{29}$

The term Bayt al-Hikmah referred to the private houses of learning founded and sponsored by the caliphs and governors. In fact, the Bayt al-Hikmah was primarily a library where there were scholars and teachers as well as translators, scribes, and bookbinders. Though this institute was set up by al-Mansūr al-'Abbās̄i, it assumed a special character under the reign of al-Ma'mūn, who entitled Hunayn bin Ishāq to translate into Arabic as many Greek works as possible. ${ }^{30}$ Because the functions and activities of the Bayt al-Hikmah increased, the number of its staff did so. ${ }^{31}$ In the reign of al-Ma'mūn, the Bayt al-Hikmah opened its doors to all scholars who wished to study therein. ${ }^{32}$ From this point of view, the Bayt al-Hikmah can be held to have played the same role as the Royal Society, founded in 1660, did in the emergence of the modern science and weltanschauung in seventeenth century England. 33

27 Kamāl al-Samarrā̄, Mukhtasar Ta'rīkh al-Tibb al-'Arab̄e, Baghdad: Yayınevi yok, 1984, vol. I, p. 350 .

28 "Bayt al-Hikmah", Mawsū'ah al-Hadārah al-Islāmiyyah, Cairo: 1426/5, S. 200, pp. 513-515.

29 See Françoise Micheau, "The Scientific Institutions in the Medieval Near East", Ecyclopedia of the History of Arabic Science, ed. by Roshdi Rashed, London: Routledge, 1996, vol. III, ss. (985-1007), p. 986.

30 Mahmūd Hamdī Zaqzūq, "Bayt al-Hikmah", al-Mawsū'ah al-Islāmiyyah al-'Āmmah, Cairo: Wizārāt al-Awqāf, 2001, p. 308.

31 See Rafīq Jujātī, "Bayt al-Hikmah", al-Mawsū'ah al-Islāmiyyah, Damascus: 2002, vol. V, pp. $678-679$

32 See al-Atrāqch̄̄, "Bayt al-Hikmah", p. 338.

33 See Steven Shapin, Bilimsel Devrim (The Scientific Revolution), Turkish translation by Ayşegül Yurdaçalış, Istanbul: İzdüşümü Publishing, 2000, p. 53. 
It is also related that the Bayt al-Hikmah was established by al-Ma'mūn in Baghdad on the model of the ancient Jundishapur Academy. Its primary mission was to translate the Greek works in science and philosophy that were brought from the Byzantine libraries by the delegate sent by al-Ma'mūn. Its director was Sahl bin Hārūn and its vice director was Sa'īd bin Hārūn. Banū al-Munajjim was one of the most famous translators and bookbinders who worked there. ${ }^{34}$

This library, founded as described and often referred to as Khizānah al-Hikmah, seems to date back to Hārūn al-Rashīd and the Barmakīs, who initiated the translations. For Hārūn al-Rashīd, having captured Amuriya and Ankara, put Yuhanna bin Miskawayh and his assistants in charge of protecting and examining the precious manuscripts existing there. With the encouragement of the Barmakiss, he also had some Indian books translated into Arabic and Persian. When the size of the original manuscripts and translations increased, Hārūn al-Rashīd felt a need to keep these works in a special place that would be known later as Khizānah al-Hikmah. And this name turned to Bayt al-Hikmah in the reign of al-Ma'mūn. ${ }^{35}$ So al-Ma'mūn seems to have given a new momentum to the progress of Islamic thought and culture. ${ }^{36}$ And though he was not the founder of the Bayt al-Hikmah, he boosted the scientific activities of this institute and opened his private library to the public use. ${ }^{37}$

The view that the Bayt al-Hikmah and the Khizanah al-Hikmah functioned as a library is corroborated by the fact that al-Ma'mūn put Sahl bin Hārūn in charge of the library of philosophy given by the ruler of Cyprus as a sign of the peace he made with al-Ma'mūn. ${ }^{38}$ The following account of Ibn Nadīm also shows that the Bayt al-Hikmah was initially named "Khizānah al-Hikmah", i.e., The Library of Philosophy: "The three collections that the Byzantine Empire sent from Constantinople to the Khizānah al-Hikmah at the behest of al-Ma'mūn contained the works of Plato, Aristotle, Hippocrates, Galen, Euclid, and Ptolemy." 39

Though we cannot precisely date the foundation of the Bayt al-Hikmah, the movement of opening to the external world and the interest in the ancient cultural and intellectual works, though halted in the reign of the caliph al-Mahdi, gained a new vigor during the reigns of Hārūn al-Rashīd and al-Ma'mūn. ${ }^{40}$ So we can

34 D. Sourdel, "Bayt al-Hikma", Encyclopaedia of Islam, Leiden: E. J. Brill, 1960, vol. I, p. 1141.

35 Jujātī, "Bayt al-Hikmah", vol. V, pp. 678-679.

36 D. Sourdel, "Bayt al-Hikma", p. 1141.

37 Micheau, "The Scientific Institutions", p. 986.

38 See "Bayt al-Hikmah", Mawsū'ah al-Hadārah al-Islāmiyyah, pp. 513-515.

39 "Bayt al-Hikmah", Mawsū'ah al-Hadārah al-Islāmiyyah, pp. 513-515.

40 See 'Atāullāh, Bayt al-Hikma, p. 29-30. 
say that the Bayt al-Hikmah was set up under the reign of al-Mansūr and reached its maturity under the rule of Hārūn al-Rashīd and al-Ma'mūn. But the period of al-Ma'mūn and his contributions to the Bayt al-Hikmah deserve a particular attention. For with al-Ma'mūn, the Bayt al-Hikmah gained an economic freedom and was no longer dependent upon the generosity and sponsorship of the caliphs and governors, enjoying its full institutionalization with its staff being put on a regular salary. ${ }^{41}$

The translation activities in the Bayt al-Hikmah can be divided into three periods:

The first period extends from the reign of al-Mansūr to that of Hārūn al-Rashīd, i.e. between the years 136 and 198 after the Hijra. This period is marked by the intensity of the translations from Persian and Indian. However, the quality of the translations was quite low. Of the most skilled translators of this period are Yahyā bin Bitrīq, Jurjis bin Jabrāīl, 'Abdullāh bin Muqaffā, Yuhanna bin Masawayh, Salām al-Abrash, Bāsit bin Matrān, Sālih bin Bahk, Manka al-Hind̄̄, Dahn al-Hind̄̄, and Ibrāhīm al-Fazarī.

The second period covers the time from the reign of al-Ma'mūn to the end of the third Hijri century, i.e., between the years 198 and 300 after the Hijra. In this period, translation of the works in a wide range of fields gained a full speed, and science progressed. Of the important translators, we can mention $\mathrm{Hu}-$ nayn bin Ishāq, Yahyā bin Batrīq, Hajjāj bin Matar, Qusta bin Luka, 'Abdulmas̄̄h bin Nā‘ima al-Hims̄̄, Ishāq bin Hunayn, Thābit bin Qurrā, and Hubash bin A'sam.

The third period covers the time between the years 300 and 350 after the Hijra. The prominent translators of this period are Matta bin Yūnus (d. 300/920), Sinān bin Thābit (d. 360/974), Yahyā bin 'Ad̄̄ (d. 364/974), Abū 'Uthmān al-Dimashq̄̄ , Abū 'Al̄̄ bin Zur'a (d. 368/978 or 378/988), Hilāl bin Hilāl al-Himsī, and 'Isā bin Sahranjat. ${ }^{42}$

As a result of the vigorous activities carried out in the Bayt al-Hikmah, most of the Greek works were translated into Arabic by the turning of the ninth century. ${ }^{43}$ In this context, we would like to point out that the translation of the works

\footnotetext{
41 See 'Atāullāh, Bayt al-Hikma, p. 203.

42 See Ibn al-Nadīm, Abū al-Faraj Muhammad bin Abū Ya'qūb Ishāq (d. 385/995), al-Fihrist, pp. 504-507, 586-593; Ibn Ab̄̄ Usaybi'a, 'Uyūn al-Anbā', pp. 246-255, 257-275; Jamāl al-Dīn Abū al-Hassan 'Alī bin Yūsuf al-Qiftī, Akhbār al-'Ulamā' bi-Akhbar al-Hukamā', Cairo: 1326 H., pp. 173-178; Zahīr al-Dīn al-Bayhaqī, Ta'rīkhu Hukamā' al-Islām, Damascus: 1946, pp. 16-18, 20; Abū Rayyān, Ta'rīkh al-Fikr, p. 21, 98-104.

43 For the list of the Greek works translated, see Ülken, Uyanış Devirlerinde Tercümenin Rolü, p. 128-167; Bekir Karlı̆̆a, Islam Düşüncesinin Batı Düşüncesine Etkileri, Istanbul: Litera Publishing, 2004, p. 218-232.
} 
of the Babylonians and the Indians, who had a profound interest and expertise in mathematics and philosophy paved the way for the rise of an Islamic institute that would survive for several centuries. In this age, the Islamic civilization evolved into a main stream into which the tributaries of other civilizations flowed. Therefore, one should not underestimate this comprehensive movement centered on the Bayt al-Hikmah by regarding it as an interest limited to the Greek philosophical works. On the contrary, philosophy simply received its lot from this overall orientation though survived longer due to the decisive role it played in the speculative and religious thought in the following centuries.

Given the diversity of the languages and the sources of translations, one may ask why the translations of the Greek philosophical works have enjoyed a dominantly frequent reference in the sources of the history of science and philosophy. One can explain this fact on the differing degrees of appeal and charm the Greek philosophy and the intellectual products of other cultures possessed. The special interest the Muslims showed in the works translated from the Greek and their passionate pursuit of the translations from different languages for accessing the Greek philosophy and the Muslim philosophers' holding the Greek masters of philosophy in high esteem as their masters -all these demonstrate that the Muslims considered the Greek thought to be superior and more attractive in rational terms than the intellectual products of other peoples. So we can conveniently say that the translations from other languages enjoyed no so much interest as the translations of the Greek works did in the Islamic world. This holds true as far at least as the references to the Greek philosophy and philosophers in the available classic works of Islamic philosophy are concerned.

But one should call a special attention to the conditions in the Islamic world that were conducive to and increased the aspirations to access the scientific and philosophical accumulation of the East and the West, opening its door to the different cultural and intellectual currents. So it must be an interesting and crucial task from the viewpoint of political and religious thought to investigate the reasons why the tree of philosophy bore fruit in the Muslim soil.

As known to the students of philosophy, the Emperor Justinian closed down the Platonic Academy in 529. However, the Greek philosophy spread in the East long ago. ${ }^{44}$ While the Byzantines took a negative attitude towards the Greek philosophy, Islam encouraged its believers to think and seek knowledge and wisdom regardless of its origin, holding the scholars in high esteem. These encouragements and principles set the stage for the intellectual and scientific progress spearheaded

44 See Etienne Gilson, Ortaçă̆da Felsefe (La Philosophie au Moyen-âge), Turkish translation by Ayşe Meral, Istanbul: Kabalcı Publishing, 2007, p. 341. 
by the Bayt al-Hikmah. Al-Ma'mūn wrote a letter to the Byzantine Emperor to assist the Muslim scholars with getting the Greek philosophical manuscripts. Initially refused this request, the Emperor however accepted it later. The caliphs made similar demands in their agreements with the Byzantine Empire and with other rulers. Al-Ma'mūn was reported to be so generous to the scholars that he granted them gold in the weight of the book they translated. This official patronage must have played an important role in that the works translated from Greek and Persian outnumbered the books translated from other languages.

Philosophy seems to have flourished in the Islamic world in some periods with state support as an expression of the official political attitude. But this is not the case all the time. For, while the translation of the philosophical works received an official support in the reigns of al-Mansūr, who was sympathetic with the Mutazilite doctrine, as well as under the rule of Hārūn al-Rashīd, al-Ma'mūn, al-Mu'tasim, and al-Wāthiq, philosophy however did not enjoy the same patronage under the rule of al-Mutawakkil, who made deliberate endeavors to check the influence and popularization of the Greek philosophy. Nevertheless, the historical facts show that al-Mutawakkil's anti-philosophical attitude could not prevent philosophy from its laying deep roots in the Islamic soils. Therefore, one cannot ground the rise and decline of philosophy in the Islamic world exclusively in the official support or ban. On the contrary, both states of philosophy should be explained in connection with the transformation in social, political, intellectual, and religious realms in the Islamic world.

One can notice such transformation in both the popular mind and the official ideology from the early years of the 'Abbasid rule onwards. Al-Ma'mūn brought the books to Baghdad which he appropriated during his military expedition to the Byzantine in the year 830 . He also allotted a considerable budget to be spent on the enrichment of the library. Moreover, he dispatched to the Byzantine a delegate that consists of Salm, the director of the Bayt al-Hikmah, Ibn al-Bitrīq, Hajjāj bin Matar, and Yuhanna bin Masawayh, requesting the Byzantine Emperor to send the books the delegate would select from the Byzantine libraries. Acquiring books from the Byzantine for big amounts of money is not confined to the caliph. On the contrary, rich and powerful families like the Banū Mūsās acquired books in the same way, expending big amount of money for this aim. ${ }^{45}$

45 See M. M. Abdulmalik al-Ān̄̄, "Abnāu Mūsā wa 'Ilm al-Hiyal" (in Bayt al-Hikma al-'Abbāsiyyah 'Araqat al-Mādī wa Ru'yat al-Hādir, 2001), vol. II, pp. 70-89; Mahmut Kaya, "Beytülhikme", Türkiye Diyanet Vakfı İslam Ansiklopedisi, Istanbul: 1992, vol. VI, pp. 88-90. 


\section{The Dream of al-Ma'mūn and the Vision of Islamic Thought}

According to the interpretation of al-Jābirī, the translation activities particularly those performed during the reign of al-Ma'mūn are not a neutral and "innocent" result effected merely by the cultural change. On the contrary, it is an important part of the general strategy the "Abbasids set against the adversary forces, the major of which was the Persian aristocracy who decided to wage an ideological war on the 'Abbasid rule as a result of the failure of its political attack.

Relying on the ideology and popular feeling of commitment to the Household of the Prophet during the uprising against the Umayyad dynasty, the Persian aristocracy came to realize that the authority perception of the then Arab Muslim society rested primarily on ideology, namely, Islamic faith. It was Islam which alleviated the intertribal wars and checked the interclass conflicts or canalized them into the wars against the external enemies of Islam. Therefore, the Persian aristocracy decided to concentrate their fight on the power center of the Arab Empire, namely, on the ideological realm. Its weapon was its religious and cultural heritage resting mainly on the gnostic thought, which implies the belief in the existence of a supra-rational source of knowledge. In fact, this is some kind of divine revelation that does not cease with the ending of the prophets.

Making use of its religious and cultural heritage that derived from the Magian, Mazdakist and Zoroastrian teachings, the Persian aristocracy launched its far-reaching ideological attack. In doing so, it aimed at undermining and destroying the Arab religion by creating doubt in it, eventually exterminating the Arab rule and seizing the state. Therefore, the 'Abbasid dynasty backed the Mutazilite ideology as part of an intellectual and religious counter-attack. The 'Abbasids both upheld the Mutazilite ideology and got translated the scientific and philosophical works of the Romans who had been the historical adversary of the Persians. So the dream of al-Ma'mūn ${ }^{46}$ was not an ordinary dream, regardless of whether it is real or fictive. ${ }^{47}$

The remarks of al-Jābir̄̄, inspired by the dream of al-Ma'mūn, on the Persian thought in particular and on gnostic thoughts in general in the context of

\footnotetext{
46 When speaking of the start of the translations of the Greek philosophical works, classic Islamic sources cite a dream which al-Ma'mūn had, in which he sees a white-skinned and red-bearded man sat on his throne, seeing himself standing before him respectfully and asking some questions. This person is Aristotle. As a result of this dream, which Ibn Nadīm claims to be one of the causes of the translations, al-Ma'mūn brings philosophers from the Byzantine. In this dream, al-Ma'mūn asks Aristotle what the good is. Aristotle responds that the good is first what is in harmony with reason, and then what is made permissible by Law, and finally what conforms to the opinion of the majority of people. See Ibn al-Nadìm, Fihrist, pp. 339-340.

47 Muhammad 'Ābid al-Jābirī, Felsefi Mirasımız ve Biz (Nahnu wa al-Turāth: Qirāātun $M u^{\prime} \bar{a}$ siratun fī Turāthinā al-Falsafiyyah), Turkish translation by Said Aykut, Istanbul: Kitabevi Publishing, 2000, p. 41.
} 
the translation of the Greek philosophical works are doubtful to stand a serious critique. First of all, if al-Ma'mūn's interest in philosophy is taken merely as a tactical and strategic move to counterbalance the strong Persian cultural sway, as set forth by al-Jābirī, there arise several problems. One of them is concerned with the character of the philosophy that came to the Islamic world. We know that this philosophy was not the pure ancient Greek philosophy; ${ }^{48}$ rather, it was a composition of diverse elements such as the Greek, the Egyptian, the Roman, the Jewish, and the Christian. This lore was saturated with gnostic ideas and replete with strenuous attempts to harmonize the Greek philosophy with religion that characterized not only the Islamic philosophy but all the Medieval philosophies as well. To realize that Islamic philosophy had such character, it suffices to look at the Neo-Platonist works that were wrongly ascribed to Aristotle and deeply influenced many of the Muslim philosophers. ${ }^{49}$ Furthermore, this philosophy reached Baghdad through the route of Alexandria, Antakya, and Harran, as noted by al-Fārābī. 50

Given that al-Jābirī lays a repeated emphasis upon Ibn Rushd's criticism of the earlier Muslim philosophers' misconception and misrepresentation of Aristotle, one may ask which philosophy al-Ma'mūn aimed at co-opting. As a matter of fact, one may explain this interpretation of al-Jābirī on the basis of his attitude towards the mystical epistemology. For example, he notes that the Easterners (al-mashriqiyyūn) are such philosophers as Balkh̄̄ (d. 321/933), Āmirī (d. 381/991) and Ibn Sīnā (d. 428/1037) who were under the influence of the Harran Academy as the Westerners are the Peripatetic and Assyrian philosophers such as Abū Bishr Matta, Yahyā bin 'Ad̄̄, and al-Sijistān̄̄. For al-Jābirī, the former's philosophical formation was characterized by the beliefs of the Sabeans who were educated in the Harran Academy, steeped in esoteric sciences, and believed in the divinity of celestial bodies as well as by the Persian nationalism and mystical beliefs. ${ }^{51}$

As regards the dream of al-Ma'mūn that reveals his passion for the Greek philosophy, we do agree with al-Jābirī that al-Ma'mūn might have sought a rational footing for his religio-political ideology, or more accurately to uphold his own Mutazilite interpretation of Islam. For the problem of evil and good occurring in the dream is presented in such a way to support the Mutazilite doctrine. However,

48 See Fahrettin Olguner, Türk İslam Düşüncesi Üzerine, Istanbul: Ötüken Publishing, 2001, pp. $132-145$.

49 Abruqlas, "al-Khayr al-Mahd" (in "Abdurrahmān Badawī, al-Aflātūinyah al-Muhdathah 'inda al-'Arab, Kuwait: Wakālah al-Matbū'āt, 1977, pp. 1-33; Kitābu Athālūjyā al-Mānsūb ilā Āristātāl̄̄s, ed. by Fr. Dieterici, Leipzig: J. C. Heinrichs'sche Buchhandlung, 1882.

50 See al-Fārab̄̄, 'Uyūn al-Masāil, Beirut: 1965, pp. 604-5; Kāmran Fān̄̄, "Jāmi'ah Bāz ve Jāmi‘ah Bastah", Tehran: Nashr-e Dānesh, 1360 (Hijri solar), vol. II/1, p. 18-29.

51 Al-Jābirī, Felsefi Mirasımız ve Biz, pp. 165-167. 
we tend to regard it as more the effect of the Greek philosophy than the cause of its translation. For the Greek philosophy must have been at least partially accessible to al-Ma'mūn so that he could make Aristotle speak in his vision.

The point that deserves the primary attention in this vision is, we think, not al-Ma'mūn's reaching a conclusion that conforms to the Mutazilite doctrine by giving reason priority over religion, but the person whom al-Ma'mūn took as authority and arbitrator, i.e., Aristotle, who is a non-Muslim. This vision is thus more appropriate to be taken as an effect or consequence of the translation movement, as opposed to Ibn al-Nadīm who tends to view it as the very cause. ${ }^{52}$ A cursory look at the historical background of the translation activities will show that the Muslims were acquainted, at least, with the logics of Aristotle in the period of al-Mansūr that precedes that of al-Ma'mūn through Ibn al-Muqaffā's translation of the Organon by Aristotle. ${ }^{53}$ In conclusion, this vision suggests that reason in the broader and philosophy in the narrower sense acquired legitimacy in a larger scale. Therefore, we prefer to view the dream of al-Ma'mūn as the reflection of the mental transformation in the Muslim world.

We find that the works al-Ma'mūn had translated concentrate on theology, ethics, and psychology. ${ }^{54}$ But this does not mean that the translations during his rule were confined to these fields. ${ }^{55}$ One should add that the oppressions and persecutions perpetrated by al-Ma'mūn and his governors, known as "al-mihna" in the history of Islam, are not directed at the Persian elements, but rather at the representatives of the literalist interpretation of Islam like Ahmad bin Hanbal (d. 241/855). ${ }^{56}$ It seems therefore more reasonable to take al-Ma'mūn's interest in philosophy and his having the Greek philosophical works translated into Arabic as an essential part of his religio-political strategy of supporting the rationalist Mutazilite doctrine. Though his initiative to collect and translate the philosophical books is possible to take as intended to support the Mutazilite doctrine, this approach nonetheless fails to encompass the whole consequences of this enterprise. For the philosophical method that developed as a result of the translations does not overlap with the theological method; on the contrary, the philosophers scorned the theologians for the latter fell back on dialectics, and not on demonstration, in its quest for truth. ${ }^{57}$

52 Cf. Ibn al-Nadīm, al-Fihrist, p. 340.

53 See Ibn Sa‘̄id, Tabaqāt al-Umam, p. 49.

54 See 'Abdulhalīm Mahmūd, al-Tafkīr al-Falsafī fì al-Islām, Beirut: Dār al-Kitāb al-Lubnānī, pp. 281-282.

55 See Ibn Sa‘īd, Tabaqāt al-Umam, p. 50-51

56 See Talat Koçyiğit, Hadisçiler ve Kelamcılar Arasındaki Münakaşalar, Ankara: Türkiye Diyanet Vakfı, 1989, pp. 192-206.

57 See İsmail Taş, Ebu Süleyman es-Sicistani ve Felsefesi, Konya: Kömen, 2006, pp. 180-185. 
In this context, one may raise the following questions: Were the activities in the Bayt al-Hikmah carried on according to a plan? Did its staff specialize in certain disciplines? To what extent do such accounts, or more accurately, interpretations conform to the reality, as those describing the Bayt al-Hikmah as not a translation office, but rather as a big complex, where copyists and bookbinders also worked, and from which the copied works were systematically distributed to the other cities of the Islamic world? ${ }^{58}$ It seems difficult to answer these questions on the grounds of the available historical data. But our primary concern is, rather than to find answers to these questions, to investigate the function of this institute in terms of revealing and expressing the mental transformation of the Muslims as well as to discover what the role it played between the eighth and tenth centuries means for the Islamic thought vis-à-vis the Western counterpart in the present age.

As regards this issue, we can note that the Muslims tended to conceive of the Greek heritage purely as intellectual efforts and products. Therefore, they paid an exclusive attention to the scientific and intellectual part of the Greek heritage, totally ignoring its religious aspects for they regarded it as either of heathen character or deprived of divine origin. This is why the Greek mythology, theogony, and tragedies caught no attention of the Muslims. ${ }^{59}$

In order to grasp how the Islamic intellectual movements emerged in eighth century Baghdad and spread all over the Muslim lands, one needs to delve deeper into the various currents that clashed in this city at that time. The cultural and intellectual vivacity of the tenth and eleventh centuries against which such luminaries of Islamic Philosophy as Zakariyyā al-Rāzī (d. 323/925), al-Fārābī (d. 339/950), and Ibn Sīnā (d. 428/1037) were raised coincided with the period in which the currents of different origins confronted and merged. The richness of the Islamic civilization in philosophy and sciences, the power of searching and discovering, and freedom of thought - all these came true thanks to this interaction. The strength of Islamic civilization lies in its very capacity to synthesize these opposite elements into a new edifice.

A philosophy of religion that appeared as a result of the theological thinking over the Qur'ān, and the Indian influences that hailed through Iran, and finally the Greek influences that made their way through the Assyrian translations -all of these confronted and collided to give birth to the indigenous character and personal nature of the Islamic thought. ${ }^{60}$ The Muslims immensely benefited from

\footnotetext{
58 See al-Atrāqch̄̄, "Bayt al-Hikmah", pp. 329-30.

59 Karlığa, Islam Düşüncesinin Batı Düşüncesine Etkileri, p. 234.

60 Ülken, Uyanış Devirlerinde Tercümenin Rolü, p. 88.
} 
the transmission of foreign cultures. As a result of the translations, there appeared a new intellectual movement in a variety of fields. With the influence of the Greek logics, the principles of Arabic grammar were laid down. In the same vein, the methodology of jurisprudence and dialectic theology made an extensive use of the Greek logics. Al-Jāhiz (d. 256/869), the great master of the Arabic belles lettres, is one of the Muslim authors who were greatly influenced by the Greek logics. The foreign influence however is most conspicuous in the dialectical theology and Islamic philosophy. ${ }^{61}$

The scientific movement that first appeared in Baghdad spread over several centers. One can draw the route of this spread in two major lines:

1. Turkish madrassahs extending from the Chinese Turkestan to Anatolia and Egypt.

2. Arab and Berber madrassahs extending from Egypt to Andalusia through Sicily and Morocco. ${ }^{62}$

After all, one should keep in mind that the Bayt al-Hikmah was an intellectual formation that revolved around the court. So though one can hardly confirm the statements that describe the Bayt al-Hikmah as an institute, a complex, a madrassah, an academy, a university ${ }^{63}$ and as a center wherefrom the ancient thoughts were disseminated to different regions of the Islamic world, it is certain that the Bayt al-Hikmah played a leading role in the transformation of the Islamic thought in a certain age. One should add that the Bayt al-Hikmah, besides its primary function as a translation office and a library, is important as an objectification and embodiment of the Muslim world's opening itself to the external world. Such factors as the mental change in the ruling elite and in its attitude towards the subjects as well as the growing Muslim capacity to establish relations with different cultures did play a role in this self-opening. In fact, the political authority built such libraries to raise the level of public education and help knowledge and learning spread among the larger sections of society. ${ }^{64}$ In conclusion, one can state that another of the fields in which the Bayt al-Hikmah contributed to the Islamic world is that of learning and education.

Given the fact that before the foundation of the Bayt al-Hikmah, the education in the Islamic world had been restricted to religious disciplines and carried on in sessions and circles in the mosques, ${ }^{65}$ namely, in an informal manner, the

\footnotetext{
61 Abū Rayyān, Ta'rīkh al-Fikr, pp. 111-12.

62 Ülken, Uyanış Devirlerinde Tercümenin Rolü, pp. 167-68.

63 See Ahmad Amīn, Duhā al-Islām, Cairo: Dār al-Ma'ārif, 1936, vol. 2, p. 64; 'Atāullāh, Bayt al-Hikma, pp. 29-30.

64 See Kaya, "Beytülhikme".

65 See 'Atāullāh, Bayt al-Hikmah, pp. 91-98.
} 
importance of the Bayt al-Hikmah to the Islamic world in that it secured the study of non-religious sciences in a universal and liberal atmosphere will be better appreciated.

\section{The Bayt al-Hikmah in the Context of Occidentalism versus Orientalism}

Discussion of the whole range of the senses of the terms "orientalism" and "occidentalism" is beyond the scope of this study. ${ }^{66}$ So let it suffice to note that by orientalism we mean regarding the East as an object and field of research and by occidentalism we designate viewing the West as an object and field of survey, no matter this research has political, scientific or ideological character. One may however ask why the terms "East" and "West" are used, and not "North" and "South". In response to this question, one may say that if the present conceptualization and debate revolved around the continent of America as a newly discovered land, the terms "North" and "South" also would be relevant to characterize some phenomena that take place in America. Therefore, it is clear that the West in this context is employed to refer to the European and the Eurocentric while the East refers primarily to the Middle East, namely, the Islamic world, and secondarily, to the Far East.

The usage of the East and the West in this sense is quite new. Though one used to speak of civilizations in geographical terms like the Egyptian civilization or the Chinese civilization or in racial terms like the Greek, Persian and Sumerian civilizations, as a result of the paradigmatic change that came in the wake of the French Revolution, the Enlightenment and the Industrial Revolution, the cultures and civilizations of the world have been reduced to the dichotomy of the West and the East. Of course one may in this context speak of the existence of a mentality that presents itself as the progressed Western culture and label the rest of the world as the backward, primitive, and third world by virtue of its scientific, technological, military, and political power.

However, as noted above, the matter who has coined these terms for what sense concerns us here only secondarily. What is of primary interest to us is this: One may talk of different civilizations and their interactions in the world history. This interaction is well exemplified by the Islamic thought that embodied the

66 For the terminological senses of orientalism and occidentalism, see Hilmi Yavuz, "Oryantalizm Üzerine Bir Giriş Denemesi", Marife, 2002, no. 3, pp. 53-63. 
unity of the East and the West in a certain period of time that preceded the present categorization of the West and the East.

When determining the Muslim stance vis-à-vis the Western civilization, a modern Muslim intellectual should reconsider the Islamic past and particularly the interactions of the Islamic civilization with other civilizations that we have termed mental transformation, which reached its peak first in the Bayt al-Hikmah. The exchange of thoughts, cultures and human products of every sort is inevitable and indispensable. ${ }^{67}$ Therefore, it is meaningless to have fears about such intellectual and cultural interactions, as shown by the past experiences. In this context, we would like to mention two of such experiences. The first is the issue that we have been trying to deal with, namely, the attitude which the Islamic world took up during its encounter with the Indian and Persian thoughts and with the Greek philosophy. Being quite positive, this attitude proves the capacity of the Islamic world to absorb and synthesize a plethora of foreign intellectual and cultural elements despite the internal reactions. ${ }^{68}$ The second is the entrance of the Greek Islamic Philosophy through Andalus back into the West, namely, into Europe in spite of the reactions, preparing the Renaissance. ${ }^{69}$

The point is that neither party relinquished its religion, nor did it lose its identity, though both experienced deep anxieties during the transformation process. In clearer terms, neither the Muslims converted themselves into another religion as a result of the philosophical thought that revolved around the Bayt al-Hikmah and swept through the whole Islamic world, nor did the Christians adopt Islam though they were deeply influenced by the Greek Islamic philosophy. On the contrary, one may speak of an opposite phenomenon: Both of the Islamic and Christian worlds gained a lot from their respective process.

This issue today stands as a more serious problem before Turkey, which is a natural and historical part of the Islamic world. With the proclamation of the Tanzimat Edict in the year 1839, we, the Turks, have officially been adopting the rising Western values this way or another, as put by Fahrettin Olguner: "Today Turkish nation has come from the Islamic civilization and stands before the Western civilization. Therefore, while some say "the only standard of the right, the good, and the beautiful is the Western criteria", some others say "let all the windows be shut to the West." It is a fact that these two views are presently clashing

67 Fahrettin Olguner, "Türk Düşüncesinin Dünü Yarını" Türk Yurdu (Türk Düşünce Hayatı Özel Sayısı), April 1991, pp. 20-25.

68 For the debates revolving around logics and linguistics but involving some ideological elements, see İsmail Taş, Ebu Süleymen es Sicistani ve Felsefesi, pp. 53-81.

69 For a detailed information about the influence of Islam on the Western world, consult Karlığa, İslam Düşüncesinin Batı Düşüncesine Etkileri. 
and alternatively (and most of the times the former one) play the dominant role in the administration of the country. But one should not view them as a threat. On the contrary, they should be seen as healthy struggles that contribute to viewing the matters from different perspectives in a country that advances in a slow but safe pace. For the currents of thought that have no alternative do not give off light continuously." 70

In determining their stand vis-à-vis the Western civilization, Turkish intelligentsia should reconsider Turkish history and especially the Turks' entrance into the Islamic civilization as well as their position in it. Exchange of thoughts, cultures and human products of every sort is inevitable and indispensable. It is natural that man in his value judgments is under the influence of the near and far environment just as he is in his epistemological judgments. ${ }^{71}$

We, modern Muslim intellectuals, should take a careful, coherent and realistic approach to the studies of the West, i.e., the occidental studies. In other words, we need to explain the rationale of occidental studies. What intellectual and political needs and necessities do require the occidental studies? What kind of mental relationship do the occidental studies have with the oriental counterparts? Should they have such a relationship? Is the motto "We should launch the occidental studies?" enough to launch them? To have a sound idea of the occidental studies or to establish a sound relationship between the Islamic thought and the occidental studies seem to depend on how we will answer these questions.

Let's revisit the issue of the explanation. What are the underlining reasons for the occidental studies? For instance, are they like the anthropological surveys conducted by the anthropologists to satisfy their sense of curiosity about the aborigines? ${ }^{72}$ I think that nobody means such a survey by this term. Furthermore, we do not observe an Eastern researcher makes an anthropological inquiry into a Western village or into a rural phenomenon or problem in the West, nor does any Easterner study London or Paris as a subject of urban anthropology.

If the occidental studies are not motivated by such an intention, so are they prompted by the intention and necessity to be an alternative to the West, as articulated by Karlı̆̆a?: "Nowadays in which we are about to step into the Information Age, the Muslim world, which is the only civilization in terms of having the intellectual potential to be alternative to the Western civilization, becoming the second greatest power with its two billion population, must train experts who will study in this field and must found well-equipped institutes for this objective.

\footnotetext{
70 Olguner, "Türk Düşüncesinin Dünü Yarını", pp. 20-25.

71 Olguner, ibid.

72 See Bronislaw Malinovski, Ilkel Toplum (Myth in Primitive Society), Turkish translation by Hüseyin Portakal, Ankara: Öteki Publishing, 1998.
} 
Just as the Western world established and developed the discipline of oriental studies, there is a great need to establish a similar discipline of the occidental studies in the Islamic world. This project will help our system of thought get rid of the Eurocentric worldview and focus on its own center and thus set the stage for the spread of a universal and pluralistic worldview." 73

Though I do share these views with all my sincerity, I think they only appear as an ideal to a sound Eastern mind and do not explain the underlying reason for the occidental studies. For they reflect the popular defensive thesis that the Muslim world can produce an alternative to the Western civilization, rather than should understand and reproduce the shared values of mankind that flourished in the West. In his following words, Karlığa expresses the underlying reasons for the occidental studies in a way that corroborates our view: "Besides, these [occidental] studies may preclude the schematic application to the whole world of such concepts as the Medieval, the Renaissance, humanism, the Reformation, modernity, the Enlightenment, secularism etc. that are produced by the Eurocentric worldview and thus are relevant [only] to the Western history, thought, civilization, and culture. For every culture produces its own model in its special historical and cultural matrix. Thus, as it is possible to view the age that is dark with respect to the Western world as the classic age with regard to the Islamic world, the period that is referred to as modern for the West may well be viewed not as modern for the Islamic world. Accordingly, the irrelevance and wrongness of the notion of Westernization that not only has for two centuries been exercising its hegemony over every sphere of life, from the way we eat and drink to the way we walk, from the way we dress to our social behavior, from our way of living to the way of our internal decoration of our houses and to our urban architecture, and from our self-perception to our perception of others, but also keeps us under a pressure in a challenging way." 74

Identifying the reason for the occidental studies as disclosing the irrelevance of the Western concepts and historical stages and as establishing the wrongness of the ideas imposed by Westernists makes one doubt it is worth undertaking such a painful task. However, I am tempted to ask whether we will take the same position if one adds such European achievements as democracy, human rights, freedom, abolition of slavery, equality, social state and the like to the notions labeled as Eurocentric. In addition, are the notions described as Eurocentric not the very criteria of the division of the East and the West? So we should regard them like Karlığa as in his following remarks: "One should not allow for the fragmentation

73 Karlığa, Islam Düşüncesinin Batı Düşüncesine Etkileri, p. 33.

74 Karlı̆̆a, ibid., p. 34. 
of such common values of humanity as science and thought due to the so-called division of the Western and Eastern, the Northern and the Southern; on the contrary, one should adopt an attitude that retains the universality, continuity and integrity of these concepts." 75

It is therefore impossible to disagree with Ülken on his following words: "We cannot say "Let's get techniques from the West but remain Eastern in our ethics and law." Neither can we say "Let's get techniques and science from the international market of thought but let our arts and philosophy be national." For there is no such international market. There is only a level of nations which have modern and shared activities. To attain to that level, we need creativity in arts, law, ethics, philosophy, and science. A nation deprived of creativity in these values can achieve no result by borrowing artistic patterns, legal forms, and philosophical works from the international market. For it is the worldview and mentality that produces them, securing the creativity and productivity of that superior culture. It is impossible to step into the modern culture without attaining a holistic worldview and without obtaining that mentality." 76

So, as the Muslim intelligentsia, we need to ask how well we know the Western civilization without predicating positive or negative values of it. Have we studied the Western civilization, which has for two centuries preoccupied our minds, in a realistic, objective, and sincere way? Or is it possible to study it in such a way? Without the completion of this process, how accurate will be our judgments on the Western culture and civilization? In the period between the eighth and ninth centuries, the Islamic world accomplished a profound and comprehensive cultural and intellectual interaction with the Western world. However, the present situation seems quite different and more complex. For the deeper and more complicated interaction grows, the heavier and harder the work of translation becomes. So we can assert that we should undertake now a task that is more challenging than that which the translators of the Greek philosophy and the forerunners of the Western Renaissance undertook in the past. For, as put by Ülken, they had to know only the Greeks through the Muslim philosophers, whereas we have to know both them and the ones who came after them. So the problem will get never resolved by leaving all these painful paths and just translating the mature works of the recent period. ${ }^{77}$

So we need a serious and holistic orientation towards the West. We do possess the historical experiences that are necessary to this task. This requires bothering

\footnotetext{
75 Karlı̆̆a, ibid., p. 34.

76 H. Z. Ülken, Türkiye'de Çağdaş Düşünce Tarihi, Istanbul: Ülken Publishing, 1994, p. 23.

77 See Ülken, ibid., pp. 17-18.
} 
oneself neither with the orientalist agenda and discourse nor with the status in which the Westerners situate the others. On the contrary, this requires having in the millennium the vision which al-Ma'mūn had in the ninth century.

\section{Summary}

The House of Wisdom (Bayt al-Hikmah) was built first as a library where the books on the sciences of the Ancients were kept. Under the sponsorship of the Caliph Al-Ma'mūn (813-833), it developed into a scientific institute where the books on Ancient Greek philosophy were translated into Arabic. The Caliph acquired many Greek manuscripts and generously supported the translation activities in the House. By the end of the century, Arabic translation of the major works of the Greek philosophy and science had been completed. Thus, the Caliph and his House paved the way for the rise and flourish of Islamic philosophy and science.

\section{Bibliography}

'Abdulhalīm Mahmūd, al-Tafkīr al-Falsafì fī al-Islām, Beirut: Dār al-Kitāb al-Lubnān̄̄, no date.

"Bayt al-Hikmah", Mawsū'ah al-Hadārah al-Islāmiyyah, Cairo: 1426/5, S. 200

Abruqlas, "al-Khayr al-Mahd" (in 'Abdurrahmān Badaw̄i, al-Aflātūniyyah al-Muhdathah 'inda al-'Arab, Kuwait: Wakālah al-Matbū'āt, 1977.

Abū al-Faraj Muhammad bin Abū Ya'qūb Ishāq Ibn al-Nadīm (d. 385/995), al-Fihrist.

Abū Qāsim ibn Sa‘id al-Andalusī, Tabaqāt al-Umam, Beirut: Imprimerie Catholique, 1912.

Ahmad Am̄̄n, Duhā al-Islām, Cairo: Dār al-Ma'ārif, 1936, vol. 2.

Al-Fārab̄̄, 'Uyūn al-Masāil, Beirut: 1965.

Bahjat Kāmil 'Abdullatīf, "Yuhanna bin Masawayh: Awwalu Raīs li-Bayt al-Hikma al-Baghdād̄̄ wa Rāid min Ruwwādi 'Ilm al-Tashrīh wa al-Tibb fī al-Khilāfah al-'Abbāsiyyah" (in Bayt al-Hikma al-'Abbāsiyyah 'Araqat al-Mādī wa Ru'yat al-Hādir, 2001) vol. II.

Bekir Karlı̆̆a, Islam Düşüncesinin Batı Düşüncesine Etkileri, Istanbul: Litera Publishing, 2004. 
Bronislaw Malinovski, Ilkel Toplum (Myth in Primitive Society), Turkish translation by Hüseyin Portakal, Ankara: Öteki Publishing, 1998.

Colin A. Ronan, "The Earliest Science in Arabia", The Cambridge Illustrated History of the World's Science, Cambridge: Cambridge University Press, 1983.

D. Sourdel, "Bayt al-Hikma", Encyclopaedia of Islam, Leiden: E. J. Brill, 1960, vol. I.

Dimitri Gutas, "al-Fikr al-Yūnān̄̄ wa al-Thaqāfah al-'Arabiyyah", Arabic translation by Nicola Ziyādah, Beirut, 1998.

Etienne Gilson, Ortaçă̆da Felsefe (La Philosophie au Moyen-âge), Turkish translation by Ayşe Meral, Istanbul: Kabalcı Publishing, 2007.

Fahrettin Olguner, "Türk Düşüncesinin Dünü Yarını" Türk Yurdu (Türk Düşünce Hayatı Özel Sayısı), April 1991.

Fahrettin Olguner, Türk Islam Düşüncesi Üzerine, Istanbul: Ötüken Publishing, 2001.

Fernand Braudel, Uygarlıkların Grameri (Grammar of Civilizations), Turkish translation by M. Ali Kılıçbay, Istanbul: İmge Publishing, 2001.

Françoise Micheau, "The Scientific Institutions in the Medieval Near East", Ecyclopedia of the History of Arabic Science, ed. by Roshdi Rashed, London: Routledge, 1996, vol. III.

George Saliba, "Translation and Translators, Islamic", Dictionary of the Middle Ages ed. by Joseph R. Strayer, New York: American Council of Learned Societies, 1989, vol. XII.

H. Z. Ülken, Türkiye'de Çağdaş Düşünce Tarihi, Istanbul: Ülken Publishing, 1994.

H. Z. Ülken, Uyanış Devirlerinde Tercümenin Rolü, Istanbul: Ülken Publishing, 1997.

Hilmi Yavuz, "Oryantalizm Üzerine Bir Giriş Denemesi”, Marife, 2002, no. 3.

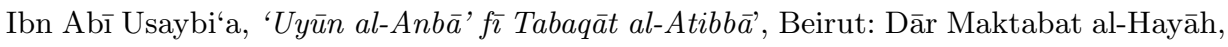
1965.

İsmail Taş, Ebu Süleyman es-Sicistani ve Felsefesi, Konya: Kömen, 2006.

Jamāl al-Dīn Abū al-Hassan 'Alī bin Yūsuf al-Qiftī, Ikhbār al-'Ulamā' bi-Akhbār al-Hukamā', Cairo: 1326 Hijri Lunar.

Kamāl al-Samarrā̄, Mukhtasar Ta'rīkh al-Tibb al-'Arab̄̄, Baghdad: Yayınevi yok, 1984, vol. I.

Kāmran Fānī, "Jāmi‘ah Bāz ve Jāmi‘ah Bastah", Tehran: Nashr-e Dānesh, 1360 (Hijri solar).

Kātib Chalab̄ì, Kashf al-Zunūn 'an Asāmī al-Kutub wa al-Funūn, Istanbul: 1941, vol. II.

Khalīl Dāwūd Zarou, al-Hayāt al-'Ilmiyya fī al-Shām, Beirut: Dār al-Āfāq al-Jadīdah, 1971.

Kitābu Athālūjyā al-Mānsūb ilā Āristātālīs, ed. by Fr. Dieterici, Leipzig: J. C. Heinrichs'sche Buchhandlung, 1882.

M. M. Abdulmalik al-Ān̄̄, "Abnāu Mūsā wa 'Ilm al-Hiyal" (in Bayt al-Hikma al-'Abbāsiyyah 'Araqat al-Mād̄̄ wa Ru'yat al-Hādir, 2001), vol. II. 
Mahmūd Hamdī Zaqzūq, "Bayt al-Hikmah", al-Mawsū'ah al-Islāmiyyah al-'Āmmah, Cairo: Wizārāt al-Awqāf, 2001.

Mahmut Kaya, "Beytülhikme", Türkiye Diyanet Vakfı İslam Ansiklopedisi, Istanbul: 1992, vol. VI.

Muhammad 'Ābid al-Jābirī, Felsefi Mirasımız ve Biz (Nahnu wa al-Turāth: Qirāātun Mu'āsiratun fī Turāthinā al-Falsafiyyah), Turkish translation by Said Aykut, Istanbul: Kitabevi Publishing, 2000.

Muhammad 'Alī Abū Rayyān, Ta'rīkh al-Fikr al-Falsafī fī al-Islām, Beirut: Dār al-Nahdah al-'Arabiyya, 1976.

Qādī Sa‘̄ìd l-Andalusī, Tabaqāt al-Umam.

Rafīq Jujātī, "Bayt al-Hikmah", al-Mawsū'ah al-Islāmiyyah, Damascus: 2002, vol. V.

Ramziya Muhammad al-Atrāqch̄̄, "Bayt al-Hikmah al-Baghdād̄̄ wa Atharuhū fī al-Harakah al-'Ilmiyyah", al-Muarrikh al-'Arab̄̄, Baghdad, vol. 14 (1980).

Şahin Filiz and Tahir Uluç, "Mawlānā Jalāl al-Dīn Rūmī: A Sufi Representative of Turkish Urban Religiosity (A Philosophical and Sociological Inquiry)", The Islamic Quarterly, vol. 48, Issue 4, Fourth Quarter 2004.

See Hadar Ahmad 'Atāullāh, Bayt al-Hikmah fī 'Asr al-'Abbāsūyȳ̄n, Cairo: Dār al-Fikr al-'Arabī, no date.

Steven Shapin, Bilimsel Devrim (The Scientific Revolution), Turkish translation by Ayşegül Yurdaçalış, Istanbul: İzdüşümü Publishing, 2000.

Tahir Uluç and Kemal Argon, "Reflections on the Unity/Trinity Polemics in Islamic Philosophy: Yahyā bin 'Adī and His Maqālah fī al-Tawhīd (Treatise on Unity)", Journal of Middle Eastern and North African Intellectual and Cultural Studies, vol. 4, issue 2, Fall 2006.

Talat Koçyiğit, Hadisçiler ve Kelamcılar Arasındaki Münakaşalar, Ankara: Türkiye Diyanet Vakfi, 1989.

Zahīr al-Dīn al-Bayhaq̄̄, Ta'rīkhu Hukamā' al-Islām, Damascus: 1946. 